\title{
GRP wt Allele
}

National Cancer Institute

\section{Source}

National Cancer Institute. GRP wt Allele. NCI Thesaurus. Code C52384.

Human GRP wild-type allele is located within 18q21.1-q21.32 and is approximately $11 \mathrm{~kb}$ in length. This allele, which encodes gastrin-releasing peptide, is involved in the regulation of both the central nervous and the gastrointestinal systems. 